\title{
TRADITIONAL HEALTH CARE POLICY INSTRUMENTS TO SUPPORT THE PUBLIC HEALTH LEVEL OF SURABAYA CITY
}

\author{
Lilik Pudjiastuti \\ Faculty of Law Universitas Airlangga \\ E-mail: pudjiastutililik29@gmail.com
}

\begin{abstract}
Traditional health care is one of the health care practices which grows in society. In addition, the existence of traditional practice is legally acknowledged by the Government Regulation No 103 of 2014 on Traditional Health Care. In its implementation of health development, the traditional health care must be reliable, secure and in accordance with religious and social culture norms. In traditional health care, there are some law-violating issues as well as the lack of public knowledge. Thus, in order to guarantee the quality of traditional health care and improve public health level, the government shall make policy in order to control the traditional health care. The policy can be in the form of laws, license, control and law enforcement. The government policy in order to guarantee the quality of traditional health care is the realization of state responsibility as stated in Article $28 \mathrm{H}$ sub article 1 and Article 28 I sub article 4 of the 1945 Constitution.
\end{abstract}

Keywords: policy, traditional health care, law enforcement

\begin{abstract}
Abstrak
Pelayanan kesehatan tradisional merupakan salah satu praktek perawatan kesehatan, yang tumbuh dalam kehidupan masyarakat. Selain itu, keberadaan praktik tradisional secara hukum diakui dengan Peraturan Pemerintah Nomor 103 Tahun 2014 tentang Pelayanan Kesehatan Tradisional. Dalam pelaksanaan pembangunan kesehatan, pelayanan kesehatan tradisional harus dapat berkhasiat, aman dan tidak bertentangan dengan norma budaya agama dan sosial. Dalam pelayanan kesehatan tradisional, ada beberapa masalah yang bertentangan dalam hukum, dan kurangnya pengetahuan dan pemahaman masyarakat terhadap itu. Dengan demikian, untuk menjamin kualitas pelayanan kesehatan tradisional dan meningkatkan derajat kesehatan masyarakat, pemerintah harus membentuk kebijakan untuk mengendalikan pelayanan kesehatan tradisional. Kebijakan tersebut bisa dalam bentuk undangundang, izin, pengawasan dan penegakan hukum. Kebijakan pemerintah dalam rangka menjamin kualitas pelayanan kesehatan tradisional merupakan realisasi dari tanggung jawab negara sebagaimana tercantum dalam Pasal 28 ayat H 1 dan Pasal 28 I ayat 4 UUD 1945 Republik Indonesia Konstitusi.
\end{abstract}

Kata kunci: kebijakan, pelayanan kesehatan tradisional, penegakan hukum

\section{Introduction}

Health development as part of national developments aims to increase people healthy life awareness, willingness and ability to improve public health level, as an investment for the productive human resources development socially and economically. The health development is implemented through various services of health care facilities either traditional or modern.

Traditional health care in Indonesia has been growing for a long time as proven by the results of Health Research data in 2013 showed that $30.4 \%$ of Indonesian people use traditional health care. It can be seen in the following figure.

In fact, the implementation of traditional health care potentially causes damages even death of the patient. For instance, the case of chiropractic treatment performed by Dr. Randall in chiropractic clinics Jakarta Pondok Indah Mall in which the patient died after treatment. ${ }^{1}$

Hardani Triyoga, Keluarga Minta Polisi Hadirkan dr. Randall Agar Kematian Allya Terungkap, detikNews, Friday $8^{\text {th }}$ January 2016. 
Some research indicate that patients prefer using traditional treatment due to unsatisfactory medical communications, surgery anxiety, medically unhealed declared by the doctor, and economic condition. ${ }^{2}$ Besides, it involves interaction between one and family, neighbors and/ or patient and his or her family interaction. ${ }^{3}$ Supported by the technology advancement, the traditional health care using testimony and promotion through mass and social media, the use of traditional health care becomes preferred.

Figure 1

Use of Traditional Health Care

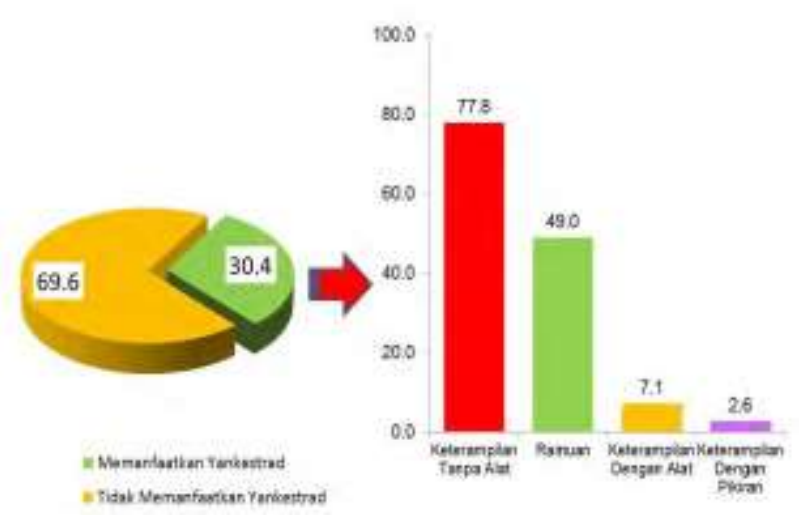

Source: Ministry of Health, Basic Health Research in 2013 and 2014.

According to Article 28 I paragraph (4) of 1945 Constitution, the state is obliged to conduct human rights compliance and enforcement, consequently, the state must take action to protect and control the implementation of the traditional health care practices. For this reason, the government has issued legislation and regulations on traditional health namely Law Number 36 Year 2009 on health and Government Regulation Number 103 Year 2014 on Traditional Health Care previously stipulated in Minister of Health Decree Number 1076/

Abdul Haris Jauhari, et.al, "Motivasi dan Kepercayaan Pasien Untuk Berobat Ke Sinse", Jurnal Berita Kesehat an Masyarakat, Vol. 24 No. 1, March 2008, Yogyakarta: Community Medical Education Program (PPKK) Medicine Faculty Universitas Gadjah Mada in collaboration with The Association of Public Medical Doctors and Indonesia Health Communities (PDK3MI), page 1.

3 See in Salem Sembiring, "Pengetahuan dan Pemanfaatan Metode Pengobatan Tradisional Pada Masyarakat Desa Suka Nalu Kecamatan Barusjahe”, Jurnal Perspektif, Vol. I No. 1, 2013, Medan: Universitas Sumatera Utara.
Menkes/SK/VII/2003 on Traditional Treatment Practices.

The Decree stated that the instrument to control, guidance and supervision is through license for the traditional healers. It aims to support traditional treatment, public protection, traditional healers' inventory, treatment type and method.

Since traditional health care is preferred as an alternative treatment, the government must develop traditional treatment based on body of knowledge, biocultural holistic dimension which becomes an Indonesian health system in accordance with the people norms of religion. This is appropriate with the recommendation of the World Health Organization/ WHO in Traditional/ Complementary Medicine 2014-2023 in terms that the Government will develop traditional health care integrated into health services system including first, Empirical Traditional Health Care; and second, Complementary Traditional Health care.

Regarding to this, Government regulation and policy for the implementation of traditional health care in order to be responsible for the benefit and safety is required. According to the background, this article will discuss the policy instruments used for development and guiding to assure the quality of yankestrad (traditional health care) in Indonesia and the effort to control and law enforcement of yankestrad in ensuring quality of nutritious and affordable health care.

\section{Discussion}

Regulation and Traditional Health Care Analysis in Indonesia

Regulation of Traditional Health Care in Indonesia

Government responsibility in fulfilling health care rights as stipulated Article $28 \mathrm{H}$ paragraph (1) of 1945 Consitution and Law Number 36 Year 2009 on Health (Health Law) means the Government is obliged to plan, organize, operate, and supervise health services which is affordable and proportional both modern and traditional health care. 
Most Indonesian people practices traditional medicine as an alternative therapy to cure the disease. This is caused by conventional treatment dissatisfaction, chronic disease care, complementary alternative therapy naturalness, and their personal interaction between client and practitioner. ${ }^{4}$ Thus, the decision is influenced by psychological and sociological factors. ${ }^{5}$ Psychological factors affecting deals with their belief in others while social factors concerns about the family support and discussion. The traditional treatment methods are basically es-tablished by one's interaction with family, neighbors and or patient interaction with the patient's family.

Based on this research, traditional treatment does not always bring an impact on one's treatment. In accordance with Jessica Christanti and Awal Prasetyo research sttating that analysis of life expectancy of KNF(nasopharyngeal cancer) patients with advanced cancer do not show different results. Hence, it can be concluded that the use of Complementary Alternative (KPA) treatment and Conventional modern therapy did not significantly change the life expectancy of KNF patients ${ }^{6}$

Traditional treatment convinces patients for three (3) characteristics. First, the belief that life is a unity of body, emotions, mind, and spirit or soul, therefore, the disease will occur if there is imbalance among the physical, emotional, mental or spiritual condition; second, traditional treatment uses a holistic approach in diagnosis and treatment rather than observing body parts; and third, the traditional treatment based on individual need regarding one's

$4 \quad$ Ridwan Kamaluddin, "Pertimbangan dan Alasan Pasien Hipertensi Menjalani Terapi Alternatif Komplementer Bekam Di Kabupaten Banyumas", Jurnal Keperawatan Soedirman (The Soedirman Journal of Nursing), Vol. 5 No. 2, 2010, Purwokerto: Health Sciences Faculty Universitas Jenderal Soedirman, page 100.

5 Ibid, page 102.

6 Jessica Christanti and Awal Prasetyo, "Tingkat Ketahanan Hidup Penderita Kanker Nasofaring Pada Berbagai Modalitas Terapi (Studi Kasus Yang Menjalani Terapi Konvensional dan Pengobatan Komplementer Alternatif)", Media Medika Indonesia, Vol. 46 No. 2, 2012, Semarang: Faculty of Medicine Universitas Diponegoro, page 144 . condition which might be different from one to another for the same disease. ${ }^{7}$ In regards to this, there are some differences between traditional health care and modern (conventional) health care as described in Table 1 below.

In accordance with the necessity of the health care rights, the Government is obliged to protect, promote, enforce and fulfill human rights by proportionally fulfilling health care rights and rights for employment and proper living. Concerning with traditional health care, a regulation is required to that balance both rights for patients and traditional treatment services instead of being removed or banned. Rather, it provides as complementary and alternative therapies. ${ }^{8}$

To balance both human rights is conducted by government through policy instruments either legal action or real action. The legal action was performed by involving legislatives by the government to realize the implementation of traditional health care for the health development. It stated in Program Directions and Pri-orities 2012 of Directorate of Traditional Com-plementary Health Care, with a strategy to ac-celerate the achievement of Strategic Plans programs and targets of the Ministry of Health for 2010-2014 to implement the integration of alternative and complementary traditional health in $30 \%$ of districts/cities (minimum of 300 Public Health Centers).

Government Regulation Number 103 Year 2014 on Traditional Health Care (PP Yankestrad) divided the yankestrad into 3 types, namely: empirical, complementary and integration. They contain subject, object and different settings as described in Table 2 below.

\footnotetext{
Loc.Cit.
}

Atik Triratnawati, "Pengobatan Tradisional, Upaya Meminimalkan Biaya Kesehatan Masyarakat Desa di Jawa”, Jurnal Manajemen Pelayanan Kesehatan, Vol. 13 No. 2, June 2010, Yogyakarta: Faculty of Medicine Universitas Gadjah Mada, page 73. 
Table 1

The differences between traditional and modern health care

\begin{tabular}{|c|c|c|}
\hline Criteria & Modern/Conventional & Traditional \\
\hline Methods & $\begin{array}{l}\text { a. Based on know- } \\
\text { ledge, clinical evid- } \\
\text { ence and in-depth } \\
\text { scientific } \\
\text { assessment. } \\
\text { b. Use medicine and } \\
\text { medical tools }\end{array}$ & $\begin{array}{l}\text { a. Based on custom passed over generation that has been } \\
\text { longer than modern medicine as an important part of his- } \\
\text { tory. } \\
\text { b. Use herbs and/or skills divided into } 4 \text { groups: Herbs tradi- } \\
\text { tional treatment; Instrument and skilled traditional } \\
\text { treat-ment, Skills without instrument; and supernatural } \\
\text { skills. } \\
\text { c. According to Government Regulation on traditional } \\
\text { health care, it is divided into: empirical, complementary } \\
\text { and integration }\end{array}$ \\
\hline Subject & $\begin{array}{l}\text { Licensed } \\
\text { practitioners }\end{array}$ & $\begin{array}{l}\text { a. Traditional Healer/ Empirical Health Care registered in } \\
\text { Traditional Healers Registered Letter (STPT) } \\
\text { b. Traditional healers who per-form complementary health } \\
\text { care with Practice License of Traditional Health Workers } \\
\text { (SIPTKT) }\end{array}$ \\
\hline $\begin{array}{l}\text { Place of } \\
\text { Practices }\end{array}$ & Health Care Facilities & $\begin{array}{l}\text { a. Traditional Health Care Facilities for complementary } \\
\text { health care } \\
\text { b. Health parlors }\end{array}$ \\
\hline
\end{tabular}

Table 2

Comparison of Traditional Health Care

\begin{tabular}{|l|l|l|l|}
\hline \multicolumn{1}{|c|}{ Topic } & \multicolumn{1}{|c|}{ Empirical } & \multicolumn{1}{c|}{ Complementary } & \multicolumn{1}{c|}{ Integration } \\
\hline Definition & $\begin{array}{l}\text { the application of tradi- } \\
\text { tional health in terms of } \\
\text { benefits and safety is em- } \\
\text { pirically proven }\end{array}$ & $\begin{array}{l}\text { the application of traditional } \\
\text { health that utilize biomed- } \\
\text { ical sciences and Biocultural } \\
\text { clarified as well as the bene- } \\
\text { fits and safety are scientific- } \\
\text { ally proven }\end{array}$ & $\begin{array}{l}\text { a health care that combines } \\
\text { conventional healthcare } \\
\text { with Traditional Comple- } \\
\text { mentary Health Care, both } \\
\text { as a complement or substi- } \\
\text { tute }\end{array}$ \\
\hline Subject & traditional healers & Traditional health workers & $\begin{array}{l}\text { Health workers together } \\
\text { with traditional health } \\
\text { workers }\end{array}$ \\
\hline Place & Health Parlors & $\begin{array}{l}\text { Traditional health care } \\
\text { facilities }\end{array}$ & Health service facilities \\
\hline License & STPT & STRTKT and SIPTKT & STRTKT and SIPTKT \\
\hline Scthod & Skills and Remedies & $\begin{array}{l}\text { Skills: manual techniques, } \\
\text { energy therapy and/or mind } \\
\text { therapy } \\
\text { Remedies: plants, animals, } \\
\text { minerals and/or essence } \\
\text { preparations (galenic) or } \\
\text { mixture of substances }\end{array}$ & $\begin{array}{l}\text { The combination of } \\
\text { conventional healthcare } \\
\text { with Traditional } \\
\text { Complementary Health Care }\end{array}$ \\
\hline Srometive and preventive & $\begin{array}{l}\text { Promotive, preventive, } \\
\text { curative, and rehabilitative }\end{array}$ & $\begin{array}{l}\text { Promotive, preventive, } \\
\text { curative, and rehabilitative }\end{array}$ \\
\hline
\end{tabular}

Source: Government Regulation Number 103 Year 2014 on Traditional Health Care

Establishment of legislation on traditional health aims to provide legal certainty and adequate protection for traditional healers and patients. This is in accordance with the legal es- tablishment related to the benefit as stated in utilititarian theory initiated by Jeremy Bentham (1748-1832). It explained that the basic objectives in making decisions provide an acceptable 
norm in stipulating public policy and social regulations. Basic objective is to look at the policies that can be set and comparing the benefits and consequences. Viewed from ethical standpoint, it is conducted by choosing policies that can provide great utility.

The growing number and types of traditional treatment as well as legal development, the Government should conduct training and supervision to make yankestrad accountable in terms of its benefits and safety corresponding to the religious norms. However, supervision and control measures toward traditional healers need public involvement. As in Surabaya, according to the Health Department of Surabaya, the number of traditional health care is 1400 providers consisting of 299 SIPT holders, 1101 STPT holders and is divided into 72 Remedies Traditional Treatments and 1328 Skills Traditional Treatments.

\section{Policy Instrument for Traditional Health Care Control}

To support health development, the government necessarily creates policy instruments to control and improve the quality of traditional health care. In accordance with the principle of legality, the main instrument is legislation formulation that provides the legal basis for the government to manage, control, supervise and enforce law.

Traditional health care has deep rooted in society yet conservation is needed. This needs to be recognized by the government and aligned its position with modern medical. Due to its rationality, the traditional health care also requires recognition and encouragement in terms of cultural research to eliminate marginal stigma. ${ }^{9}$ Therefore, the government shall establish traditional health worker in higher education, as Airlangga University which provides a traditional health study program at Vocational Faculty. Similarly, ministry of health polytechnics in Surakarta has provided department of acu- puncture and herbal medicine program which aims to produce traditional health worker who have competence assurance to improve public trust of traditional health.

In Furthermore, improvement of health human resources needs to be well supported by the presence of health promotion efforts in the community about the selection of safe and useful alternative medicine which can give knowledge to people to select the right treatment.

\section{Traditional Health Care Law Enforcement in} Surabaya

Traditional Health Care Supervision

Health care is an activity related to one wellbeing, consequently, there should be an instrument to monitor traditional treatment services. To assure the safety and efficacy of traditional treatment, the Ministry of Health or the Provincial Health Agency Chief and/or the District/ City Health Department has the authority to control the traditional health personnel, traditional healers and traditional health care providers. In accordance with the division of government affairs, District/City Health Department has authorities to supervise: first, STPT and Practice License of Traditional Health Workers (SIPTKT); second, traditional treatment which is integrated in Type $C$ and $D$ hospiltas; third, Implementation of traditional treatment, such as SPA, Acupuncture etc. Provincial Health Department has the authority to conduct supervision on health traditional integrated to Type $B$ Hospitals while the Ministry of Health has the authority to conduct supervision to those which are integrated to Type A Hospitals.

Basically, the supervision activities of traditional medicine is to control health workers, treatment, and location. Supervision would be optimally performed if it involves the participation of professional organizations and society. It is very important to create favorable circumstances in business and the fulfillment of the

\footnotetext{
${ }^{9}$ Ibid, page 75 .
} 
rights and interests of both parties. ${ }^{10}$ The use of traditional medicine has not been integrated with traditional health services, so that health services have traditionally been a medium for the circulation of the traditional medicine can not be guaranteed safety and usefulness ${ }^{11}$ With the involvement of the community in providing law enforcement information on traditional health care business in the form of spa and massage parlors/ reflexology in Surabaya are optimal, it can be seen in Table 3 .

Table 3

Administrative law enforcement on empirical health care business in Surabaya

\begin{tabular}{|l|l|l|l|}
\hline Year & Warning & $\begin{array}{l}\text { Government } \\
\text { Coercion }\end{array}$ & Information \\
\hline 2014 & $\begin{array}{l}13 \text { busi- } \\
\text { nesses }\end{array}$ & $\begin{array}{l}\text { Closed 4 } \\
\text { businesses }\end{array}$ & $\begin{array}{l}1 \text { new } \\
\text { license and } \\
\text { renaming }\end{array}$ \\
\hline 2015 & $\begin{array}{l}20 \text { busi- } \\
\text { nesses }\end{array}$ & $\begin{array}{l}\text { Closed 1 } \\
\text { business }\end{array}$ & \\
\hline 2016 & $\begin{array}{l}34 \text { busi- } \\
\text { nesses }\end{array}$ & & \\
\hline Etotal & $\begin{array}{l}67 \text { busi- } \\
\text { nesses }\end{array}$ & & \\
\hline
\end{tabular}

Source: Surabaya Health Department, 2016

According to data from the Health Department of Surabaya City, law enforcement on providers or therapist in Surabaya has not effectively impelemented for several obstacles, first, inadequate regulations that support supervision and training; second, different level of health workers understanding; third, unclear standardization of traditional treatment methods; fourth, the lack of standardization of education and training of traditional healers; fifth, traditional healers professional organization has not been established; and sixth, lack of coordination between private institution and government, local governments in terms of yankestrad training and development.

10 Rudy Susanto, Faisal Abdullah and Sabir Alwy, "Pengawasan Peredaran Obat Tradisional di Singkawang", Jurnal Penelitian Hukum, Vol. 2 No. 2, 2013, Makasar: Faculty of Law Universitas Hasanuddin, page 177.

11 Lilik Pudjiastuti, "Licensing And Legalization of Traditional Medicine To Ensure Public Health Quality", Jurnal Dinamika Hukum, Vol. 15 No. 2, May 2015, Purwo kerto: Law Faculty Universitas Jenderal Soedirman, page 127.
Implementation of Administrative Sanctions and Criminal Provisions

An administrative sanction is a follow up of supervision, thus, it is part of the repressive administrative law enforcement. Administrative sanction is given by the government/local government without going through a judicial procedure which aims to stop acitivity and/or business and restore the previous condition. For this reason, the authorized agency is the Minister of Health, Provincial Health Department and District/ City Health Department. Under Article 83 of Government Regulation on Traditional Health Care, administrative sanction is imposed to: Traditional Healers, Traditional Health Workers and/ or Organizers of Traditional Health Care while administrative sanctions include oral warning, warning letter, STPT cancellation and license revocation (SIPTKT and/or Operational License).

In addition to the application of administrative sanctions, law enforcement is also required through the imposition of criminal sanctions for violations considering the purpose of applying repertoire administrative sanctions. Due to the risk of person's health or even death in traditional care business, criminal sanction is also imposed following administrative sanction. Criminal sanctions based on Article 191 of Law Number 36 Year 2009 on Health, Article 62 of Law Number 8 Year 1999 on Consumer Protection and Article 359, Article 360 and Article 361 on Penal Code. Application of these cumulation sanctions has been implemented by Jakarta government to close the Chiropractic First clinic in Pondok Indah Mall and assign Dr. Randdal Cafferty as a suspect for the death of Allya Siska.

\section{Traditional Health Care Alternative Solutions}

As we know that traditional health care is an acknowledged health service as one of health efforts, both nationwide through the Health Law and worldwide. Therefore, the utilization of health services need development and improvement, either individually or integrated in a comprehensive health care system in an effort to improve the health of Indonesia people. 
Coaching, supervision and law enforcement of the implementation of traditional health care can be done through: first, Coaching. Traditional health care coaching is done by: Improving health human resources through formal and non-formal educational institutions to improve the quality of traditional health care; Establishing traditional health professional organizations to conduct training for its members; and Improving public health promotion so people are abe to choose the appropriate treatment. second, Control. Control of traditional health care can be made through: Integration of traditional health care with modern health care at the level of primary health care facilities (health centers and hospitals), it will provide easy control over the treatment violation; and License for the establishment and licensing of health care for the actor (traditional health workers or traditional healers) as a screening efforts on their competence.

Coaching and control are preventive efforts in ensuring the implementation of qualified health services. As a result, by the government, professional organizations and community involvement, it will affect the increasing violation of traditional health care. As we know that traditional health care has deep rooted in community so it cannot be eliminated and should be preserved by its safety, quality and benefits.

\section{Conclusion}

Traditional health care is part of health efforts that have been rooted in Indonesian culture. For this reason, the implementation of traditional health care that still has an impact on people's health should not be abolished. Rather, the quality and safety needs improving to be in accordance with modern health care (integration). Meanwhile, the law enforcement to traditional treatments are repressive efforts, in which law enforcement is carried out after the violation or the loss or death of a person happens. Thus, the implementation of traditional treatment needs to optimize the coaching, both subject of the treatment and public in order to choose the best treatment. Enforcement of this law, either administrative or criminal sanction should involve traditional health organizations and community to optimize the effectiveness of law enforcement.

\section{Suggestion}

Government, local authorities and organizers of modern health cooperate with traditional health care in the implementation of health care was performed by opening a practice together and support each other. To support the policy, the government and local governments provide infrastructure support in the form of laws and improvement of traditional health human resources.

\section{References}

Christanti, Jessica and Awal Prasetyo. "Tingkat Ketahanan Hidup Penderita Kanker Nasofaring Pada Berbagai Modalitas Terapi (Studi Kasus Yang Menjalani Terapi Konvensional dan Pengobatan Komplementer Alternatif)". Media Medika Indonesia. Vol. 46 No. 2. 2012. Semarang: Faculty of Medicine Universitas Diponegoro;

Jauhari, Abdul Haris et.al. "Motivasi dan Kepercayaan Pasien Untuk Berobat Ke Sinse". Jurnal Berita Kesehatan Masyarakat. Vol. 24 No. 1 Maret 2008. Yogyakarta: Community Medical Education Program (PPKK) Faculty of Medicine Universitas Gadjah Mada in collaboration with the Medical Doctors Association of Community and Public Health Indonesia (PDK3MI);

Kamaluddin, Ridwan. "Pertimbangan dan Alasan Pasien Hipertensi Menjalani Terapi Alternatif Komplementer Bekam Di Kabupaten Banyumas". Jurnal Keperawatan Soedirman (The Soedirman Journal of Nursing). Vol. 5 No. 2 2010. Purwokerto: Health Sciences Faculty Universitas Jenderal Soedirman;

Kementerian Kesehatan Republik Indonesia. 2014. Hasil Riset Kesehatan Dasar Tahun 2013. Jakarta: Kementerian Kesehatan Republik Indonesia;

Pudjiastuti, Lilik. "Licensing And Legalization Of Traditional Medicine To Ensure Public Health Quality". Jurnal Dinamika Hukum. 
Vol. 15 No. 2. May 2015. Purwokerto: Faculty of Law Universitas Jenderal Soedirman;

Sembiring, Salem. "Pengetahuan dan Pemanfaatan Metode Pengobatan Tradisional Pada Masyarakat Desa Suka Nalu Kecamatan Barusjahe". Jurnal Perspektif. Vol. I No. 1. 2013. Medan: Universitas Sumatera Utara;

Susanto, Rudy. Faisal Abdullah and Sabir Alwy. "Pengawasan Peredaran Obat Tradisional di Singkawang". Jurnal Penelitian Hukum.
Vol. 2 No. 2 2013. Makasar: Law Faculty Universitas Hasanuddin;

Triratnawati, Atik. "Pengobatan Tradisional. Upaya Meminimalkan Biaya Kesehatan Masyarakat Desa di Jawa". Jurnal Manajemen Pelayanan Kesehatan. Vol. 13. No. 2 June 2010. Yogyakarta: Faculty of Medicine Universitas Gadjah Mada;

Triyoga, Hardani. Keluarga Minta Polisi Hadirkan dr. Randall Agar Kematian Allya Terungkap. detikNews. 8 January 2016. 